\title{
A new species of Aeneator Finlay, 1926 (Mollusca, Gastropoda, Buccinidae) from northern Chile, with comments on the genus and a key to the Chilean species
}

\author{
Juan Francisco Araya ${ }^{1, \dagger}$ \\ I Universidad de Chile, Facultad de Ciencias, Las Palmeras 3425. Nuñoa. Santiago. Chile \\ † urn:lsid:zoobank.org:author:443B4F42-FB13-42A6-B92B-1B0F835698A9 \\ Corresponding author: Juan Francisco Araya (jfaraya@u.uchile.cl)
}

Academic editor: Nathalie Yonow | Received 3 December 2012 | Accepted 27 December 2012 | Published 14 January 2013

urn:lsid:zoobank.org:pub:13316CEA-OB85-4883-BBC6-503B99831EF8

Citation: Araya JF (2013) A new species of Aeneator Finlay, 1926 (Mollusca, Gastropoda, Buccinidae) from northern Chile, with comments on the genus and a key to the Chilean species. ZooKeys 257: 89-101. doi: 10.3897/zookeys.257.4446

\begin{abstract}
A new species of the genus Aeneator Finlay, 1926 is described from off the coast of Caldera $\left(27^{\circ}\right)$, northern Chile. Aeneator martae sp. n. has a small, broad, stout, angulated shell with more prominent axial ribs and a more obviously keeled periphery than all previously named Chilean species. Comparisons are provided with all other South American named species of Aeneator.
\end{abstract}

\section{Keywords}

New taxa, East Pacific, deep water

\section{Introduction}

The genus Aeneator Finlay, 1926 comprises a group of deep-water gastropods of moderate size, distributed in the South Pacific Ocean around New Zealand (Powell 1979, Beu 1979) and Chile (Rehder 1971, McLean and Andrade 1982, Fraussen and Sellanes 2008). Almost all the species have offshore distributions, and they are common on the sea floor (Dawson 1965, Powell 1979, Beu and Maxwell 1990). Their elongate fusiform shells have rounded whorls with a subsutural concavity, a lip with a broad shallow sinus below the suture, and a sculpture of strong axial ribs overridden by spiral cords (McLean and Andrade 1982).

Copyright Juan Francisco Araya. This is an open access article distributed under the terms of the Creative Commons Attribution License 3.0 (CC-BY), which permits unrestricted use, distribution, and reproduction in any medium, provided the original author and source are credited. 
In the southeastern Pacific the genus encompasses five extant species: Aeneator castillai McLean \& Andrade, 1982, Aeneator fontainei (d'Orbigny, 1839), Aeneator (Ellicea) loisae Rehder, 1971, Aeneator portentosus Fraussen \& Sellanes, 2008 and Aeneator prognaviter Fraussen \& Sellanes, 2008. The distribution of these species ranges from Bahía Independencia $\left(14^{\circ} \mathrm{S}\right)$, in the south of Peru to Canal Moraleda $45^{\circ} 22^{\prime} \mathrm{S}$, southern Chile (Osorio et al. 2006). Their bathymetric range is from $10 \mathrm{~m}$ depth for $A$. fontainei collected at Mejillones Bay, in the north of Chile (Guzmán et al. 1998, Laudien et al. 2007) to $800 \mathrm{~m}$ depth for $A$. portentosus, collected off Iquique (Fraussen and Sellanes 2008). Most of the species have been recovered in the trawls of the local shrimp industry (McLean and Andrade 1982, Rehder 1971, Párraga 2012, Queirolo et al. 2011), and very little is known of their population biology, ecology and conservation status.

The present work describes a new species of Aeneator from northern Chile based on shell morphological features. Criteria were shell shape, number of primary spiral cords, development of secondary spirals, and axial sculpture. An identification key, based on shell characters, is given for all the extant Chilean Aeneator species.

\section{Material and methods}

Material examined: Aeneator martae sp. n. types, Chile, Region of Atacama, Caldera, holotype MZUC 37890, paratype 1 MZUC 37891, paratype 2 MZUC 37892, paratype 3 MG 200105.

Examination was made of shell only specimens; all measurements were made with vernier callipers $( \pm 0.1 \mathrm{~mm})$. For the measure of length of aperture and angle of the spire, the methodology of Dépraz et al. (2009) and Chiu et al. (2002) was used.

Abbreviations: KF; Private collection of Mr Koen Fraussen, Aarschot, Belgium, MG: private collection of the author, section marine Gastropoda, MZUC; Museo de Zoología de la Universidad de Concepción, Concepción, Chile, RC Coll; private collection of Mr Ricardo Catalán, Servicio Nacional de Pesca, Chile.

\section{Results}

\section{Systematics}

Class: Gastropoda Cuvier, 1797

Order: Neogastropoda Wenz, 1938

Superfamily: Buccinoidea Rafinesque, 1815

Family: Buccinidae Rafinesque, 1815

\section{Genus: Aeneator Finlay, 1926:414}

Type species. Verconella marshalli Murdoch 1924 (by original designation), Pleistocene and recent, New Zealand. 


\section{Aeneator martae sp. n.}

urn:lsid:zoobank.org:act:73AC9156-214E-4941-BFF6-0F94F8E17381

http://species-id.net/wiki/Aeneator_martae

Figs 1-14, 18, Tables 1, 2, 3

Type material. Holotype (MZUC 37890), $47.9 \mathrm{~mm}$. Chile, off Caldera $\left(27^{\circ} 04^{\prime} \mathrm{S}\right.$, $\left.70^{\circ} 50^{\prime} \mathrm{W}\right), 550-600 \mathrm{~m}$ depth, live collected on shrimp trawl nets, January 2001, S. Castillo leg. Paratype 1 (MZUC 37891), length $44.0 \mathrm{~mm}$. Paratype 2 (MZUC 37892), $41.7 \mathrm{~mm}$, Paratype 3 (MG 200105), length $40.2 \mathrm{~mm}$. All the paratypes with same locality as the holotype.

Distribution. Known only from the type locality; Chile, Region de Atacama, Caldera $\left(27^{\circ} 04^{\prime} \mathrm{S}, 70^{\circ} 50^{\prime} \mathrm{W}\right)$, 550-600 $\mathrm{m}$ depth.

Diagnosis. A small species of Aeneator, height up to $47.9 \mathrm{~mm}$, shell stout, inside of aperture pale orange, exterior sculptured by well-defined axial ribs, spiral cords, and a conspicuous stepped shoulder.

Description. Shell small for genus (height up to $47.9 \mathrm{~mm}$, Table 1), thick, solid, fusiform, chalky white to pale brownish, inside of aperture pale orange. Shape broad, angulate, length of aperture and canal more than half length of shell, width/height ratio 0.53

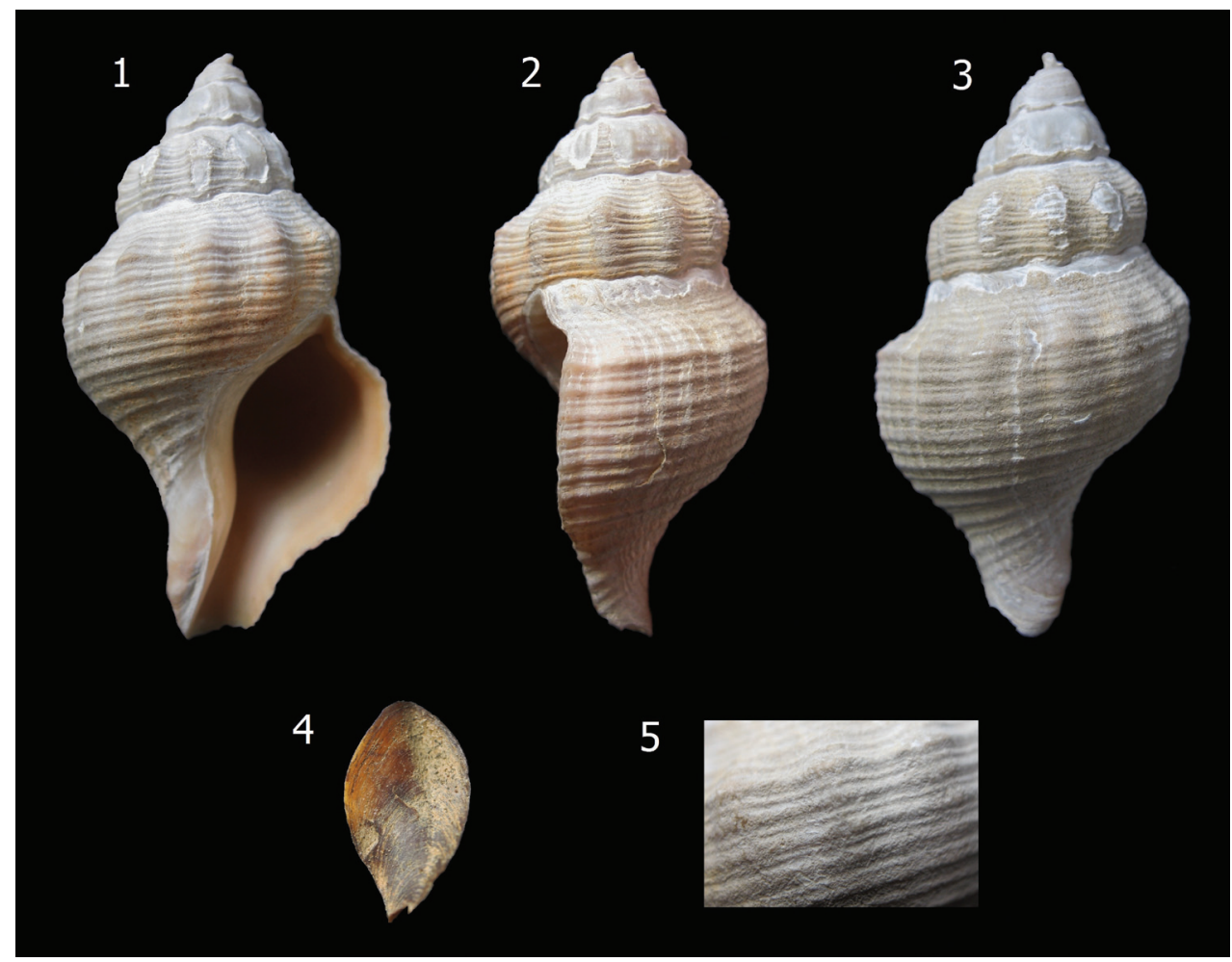

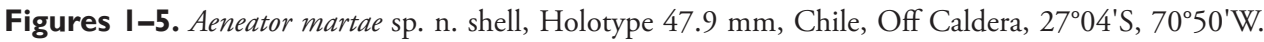
550-600 m. MZUC 37890. 
Table I. Aeneator martae sp. n. measurements of specimens. (\%) means percentage compared to the total length of the shell.

\begin{tabular}{l|c|c|c|c}
\hline & $\begin{array}{c}\text { Maximum length } \\
(\mathbf{m m})\end{array}$ & $\begin{array}{c}\text { Maximum width } \\
(\mathbf{m m})\end{array}$ & Length of aperture & Width/Length \\
\hline Holotype & 47.9 & 25.6 & $26.8(56 \%)$ & 0.53 \\
\hline Paratype 1 & 44.0 & 23.6 & $27.9(57 \%)$ & 0.54 \\
\hline Paratype 2 & 41.7 & 23.4 & $23.0(57 \%)$ & 0.56 \\
\hline Paratype 3 & 40.2 & 22.1 & $22.6(56 \%)$ & 0.55 \\
\hline Average & 43.4 & 23.6 & $25.1(56 \%)$ & 0.54 \\
\hline
\end{tabular}

to 0.56 , whorls convex apart from slightly concave sutural ramp, suture shallow but impressed. Spire angle $63^{\circ}$ to $68^{\circ}$. Protoconch and upper teleoconch whorls missing, remaining whorls about 4.5 , last 3 with sculpture intact with 7-9 primary spiral cords, interspaces each occupied by one narrow, well defined secondary cord. Last whorl with 16-18 spiral cords, more prominent at periphery of shell than elsewhere, forming a distinct keel. Spire whorls with 24-28 pronounced axial ribs, interspaces deep, each almost equal to a rib in width. Last whorl with 14-15 such ribs. Ribs more pronounced towards the anterior end of shell. Aperture ovate. Parietal and columellar area well-defined, glazed; outer lip thin, slightly crenulated, without lirae or teeth. Siphonal canal short, open, directed slightly to left. Operculum large, thin, dark brown, elongate, nucleus terminal, tip sharp.

Etymology. Named in honour of Mrs Marta Araya, Caldera, Chile, who presented the specimens to the author.

Remarks. In Chile the genus Aeneator encompasses five extant species: A. castillai, found from Coquimbo $\left(29^{\circ} 55^{\prime} S\right)$ to Punta Peñablanca $\left(33^{\circ} 22^{\prime} S\right)$ in $200-450 \mathrm{~m}$ (McLean and Andrade 1982), A. fontainei, the most common species, with records from Bahía Independencia $\left(14^{\circ} S\right)$ in the south of Peru (McLean and Andrade 1982) to Estero Elefantes, $46^{\circ} 05^{\prime} \mathrm{S}$ (Osorio et al. 2006) and with a bathymetric range of 10 m near Mejillones (Guzmán et al. 1998, Laudien et al. 2007) to $421 \mathrm{~m}$ for a specimen collected off Coquimbo (Figs 27-30), A. (Ellicea) loisae, distributed from Caldera $\left(27^{\circ} 04^{\prime} \mathrm{S}\right)$, for material examined in this work (Figs 27-30), to Canal Moraleda $\left(45^{\circ} 22^{\prime} \mathrm{S}\right)$, in the fords area (Osorio et al. 2006) with a bathymetric range of $200 \mathrm{~m}$ (McLean \& Andrade 1982) to $465 \mathrm{~m}, A$. portentosus reported only form the original locality off Iquique ( $\left.21^{\circ} 19^{\prime} \mathrm{S}\right)$ in $605 \mathrm{~m}$ and off Coquimbo at $800 \mathrm{~m}$ and $A$. prognaviter, distributed off Antofagasta (22 $51^{\prime} \mathrm{S}$ ) in $318 \mathrm{~m}$ (Fraussen and Sellanes 2008) and in $748 \mathrm{~m}$ off Iquique for material examined in this work (Fig. 37). Data on the localities of Chilean species of Aeneator is provided in Table 3.

In size, the shell of Aeneator martae sp. n. is similar to A. prognaviter (Figs 20, 37, 38) and $A$. portentosus (Figs 35, 36). However, the former of these two can be clearly differentiated from the new species by its wider and shorter siphonal canal, less numerous and more curved axial ribs and a thinner, snow white shell (Fraussen and Sellanes 2008). From $A$. portentosus the new species differs by having a much wider, thicker shell with a shorter spire, a more elongate aperture, dominant axial sculpture and less rounded whorls. Moreover $A$. portentosus exhibit a very distinctively sculptured peri- 


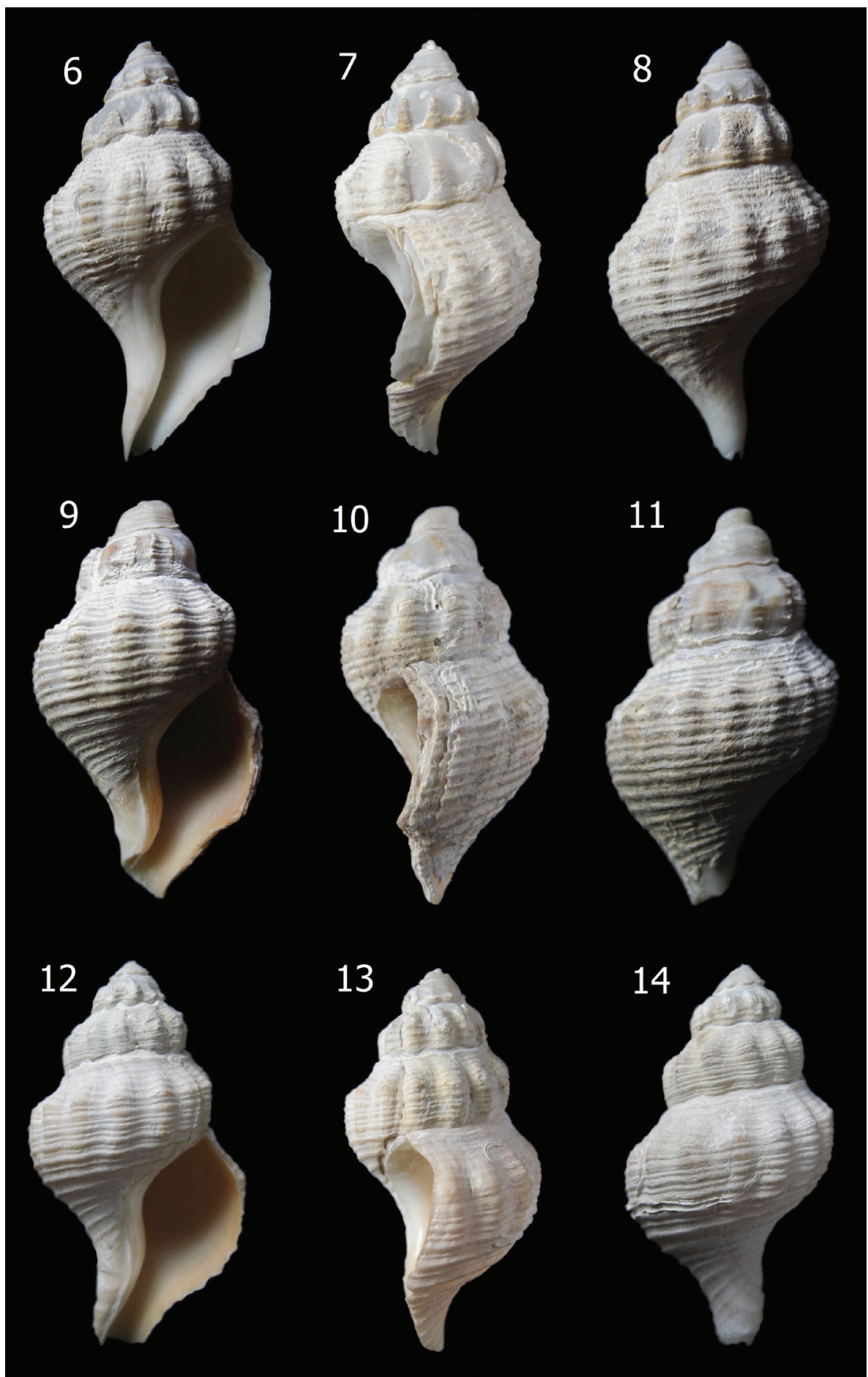

Figures 6-I4. Aeneator martae sp. n. shells. 6-8 Paratype 1 (MZUC 37891), $44.0 \mathrm{~mm}$ height 9-I I Paratype 2 (MZUC 37892), 41.7 mm height I 2-I 4 Paratype 3 (MG 200105), 40.2 mm height. 
Table 2. Synthesis of characters of the Chilean species of Aeneator Finlay, 1926 based on Rehder (1971), McLean and Andrade (1982), Fraussen and Sellanes (2008) and material examined in this work.

\begin{tabular}{|c|c|c|c|c|c|c|}
\hline & $\begin{array}{c}\text { Aeneator } \\
\text { castillai }\end{array}$ & $\begin{array}{l}\text { Aeneator } \\
\text { fontainei }\end{array}$ & $\begin{array}{c}\text { Aeneator } \\
\text { loisae }\end{array}$ & $\begin{array}{c}\text { Aeneator } \\
\text { portentosus }\end{array}$ & $\begin{array}{c}\text { Aeneator } \\
\text { prognaviter }\end{array}$ & $\begin{array}{c}\text { Aeneator } \\
\text { martae sp. } \mathrm{n} .\end{array}$ \\
\hline Length & 85.7 & 85.8 & 104 & 45.5 & 32.2 & 47.9 \\
\hline $\begin{array}{l}\text { Width / } \\
\text { Length }\end{array}$ & $0.50-0.51$ & $0.48-0.54$ & $0.43-0.48$ & $0.49-0.59$ & $0.55-0.60$ & $0.54-0.56$ \\
\hline $\begin{array}{l}\text { Aperture } \\
\text { length/ total } \\
\text { length }\end{array}$ & $0.55-0.63$ & $0.55-0.56$ & $0.54-0.56$ & $0.43-0.52$ & $0.49-0.53$ & $0.55-0.56$ \\
\hline Spire angle & $50^{\circ}$ & $51^{\circ}-57^{\circ}$ & $44^{\circ}-46^{\circ}$ & $44^{\circ}-51^{\circ}$ & $60^{\circ}$ & $63^{\circ}-68^{\circ}$ \\
\hline $\begin{array}{l}\text { Axial ribs on } \\
\text { last whorl }\end{array}$ & $\begin{array}{c}\text { 16, absent in } \\
\text { subsutural } \\
\text { area }\end{array}$ & $12-15$ & Faint, absent & Faint, absent & 22 , bent & $\begin{array}{l}\text { 14-15, } \\
\text { straight }\end{array}$ \\
\hline $\begin{array}{l}\text { Spiral cords } \\
\text { in last whorl }\end{array}$ & $\begin{array}{c}12-15 \\
\text { brown } \\
\text { primary, } 1-3 \\
\text { secondary } \\
\text { in each } \\
\text { interspace }\end{array}$ & $\begin{array}{c}12-15 \\
\text { brown } \\
\text { primary, 3-5 } \\
\text { secondary } \\
\text { in each } \\
\text { interspace }\end{array}$ & $\begin{array}{c}9-10 \\
\text { primary, } \\
\text { many } \\
\text { secondary }\end{array}$ & 20 & $20-24$ & $\begin{array}{c}16-18 \\
\text { primary, } 7-9 \\
\text { secondary }\end{array}$ \\
\hline $\begin{array}{l}\text { Siphonal } \\
\text { canal }\end{array}$ & $\begin{array}{l}\text { short, } \\
\text { twisted }\end{array}$ & $\begin{array}{c}\text { medium to } \\
\text { long, straight }\end{array}$ & long & $\begin{array}{l}\text { short, broad, } \\
\text { slightly bent }\end{array}$ & short, broad & $\begin{array}{c}\text { short, } \\
\text { slightly } \\
\text { curved to } \\
\text { left }\end{array}$ \\
\hline Aperture & ovate & ovate & $\begin{array}{c}\text { elongate } \\
\text { ovate }\end{array}$ & round & oval & oval \\
\hline Shell color & brown & $\begin{array}{l}\text { white - } \\
\text { yellowish }\end{array}$ & white & snow white & snow white & $\begin{array}{c}\text { white, pale } \\
\text { brownish }\end{array}$ \\
\hline Distribution & $\begin{array}{c}29^{\circ} 55^{\prime} \mathrm{S} \text { to } \\
39.1^{\circ} \mathrm{S}\end{array}$ & $\begin{array}{c}14^{\circ} 13^{\prime} \mathrm{S} \text { to } \\
46^{\circ} \mathrm{S}\end{array}$ & $\begin{array}{c}27^{\circ} 04^{\prime} \mathrm{S} \text { to } \\
53.7^{\circ} \mathrm{S}\end{array}$ & $\begin{array}{l}21.19^{\circ} \mathrm{S} \text { and } \\
29.95^{\circ} \mathrm{S}\end{array}$ & $\begin{array}{c}21^{\circ} 19^{\prime} \mathrm{S} \text { and } \\
22^{\circ} 51^{\prime} \mathrm{S}\end{array}$ & $27^{\circ} 04^{\prime S}$ \\
\hline
\end{tabular}

Table 3. Table of localities of Chilean species of Aeneator Finlay, 1926 based on Rehder (1971), McLean and Andrade (1982), Fraussen and Sellanes (2008), and material examined in this work.

\begin{tabular}{l|l|l|l}
\hline \multicolumn{1}{c|}{ Species } & \multicolumn{1}{|c|}{ Latitude } & \multicolumn{1}{c}{ Longitude } & Depth $(\mathbf{m})$ \\
\hline A. castillai & $29^{\circ} 55^{\prime} \mathrm{S}$ to $33^{\circ} 22^{\prime} \mathrm{S}$ & $71^{\circ} 53^{\prime} \mathrm{W}$ to $71^{\circ} 20^{\prime} \mathrm{W}$ & $200-450$ \\
\hline A. fontainei & $14^{\circ} 14^{\prime} \mathrm{S}$ to $46^{\circ} 05^{\prime} \mathrm{S}$ & $76^{\circ} 11^{\prime} \mathrm{W}$ to $73^{\circ} 41^{\prime} \mathrm{W}$ & $10-421$ \\
\hline A. loisae & $27^{\circ} 04^{\prime} \mathrm{S}$ to $45^{\circ} 22^{\prime} \mathrm{S}$ & $73^{\circ} 21^{\prime} \mathrm{W}$ to $70^{\circ} 50^{\prime} \mathrm{W}$ & $200-465$ \\
\hline A. martae & $27^{\circ} 04^{\prime} \mathrm{S}$ & $70^{\circ} 50^{\prime} \mathrm{W}$ & $550-600$ \\
\hline A. portentosus & $21^{\circ} 19^{\prime} \mathrm{S}$ to $29^{\circ} 55^{\prime} \mathrm{S}$ & $71^{\circ} 20^{\prime} \mathrm{W}$ to $70^{\circ} 09^{\prime} \mathrm{W}$ & 800 \\
\hline A. prognaviter & $21^{\circ} 19^{\prime} \mathrm{S}$ to $22^{\circ} 51^{\prime} \mathrm{S}$ & $70^{\circ} 24^{\prime} \mathrm{W}$ to $70^{\circ} 09^{\prime} \mathrm{W}$ & $600-748$ \\
\hline
\end{tabular}

ostracum (Fig. 19), with low axial ridges, very different from all the other Chilean $A e-$ neator species. A periostracum is absent in the examined specimens of $A$. martae sp. $\mathrm{n}$.

Aeneator castillai (Figs 33, 34), and A. fontainei (Figs 21-26) differ markedly from the new species by their much larger shells, reaching up to $85.8 \mathrm{~mm}$, more fusiform shells, with a much less stepped or indistinct shoulder, lower and fewer axial ribs, 


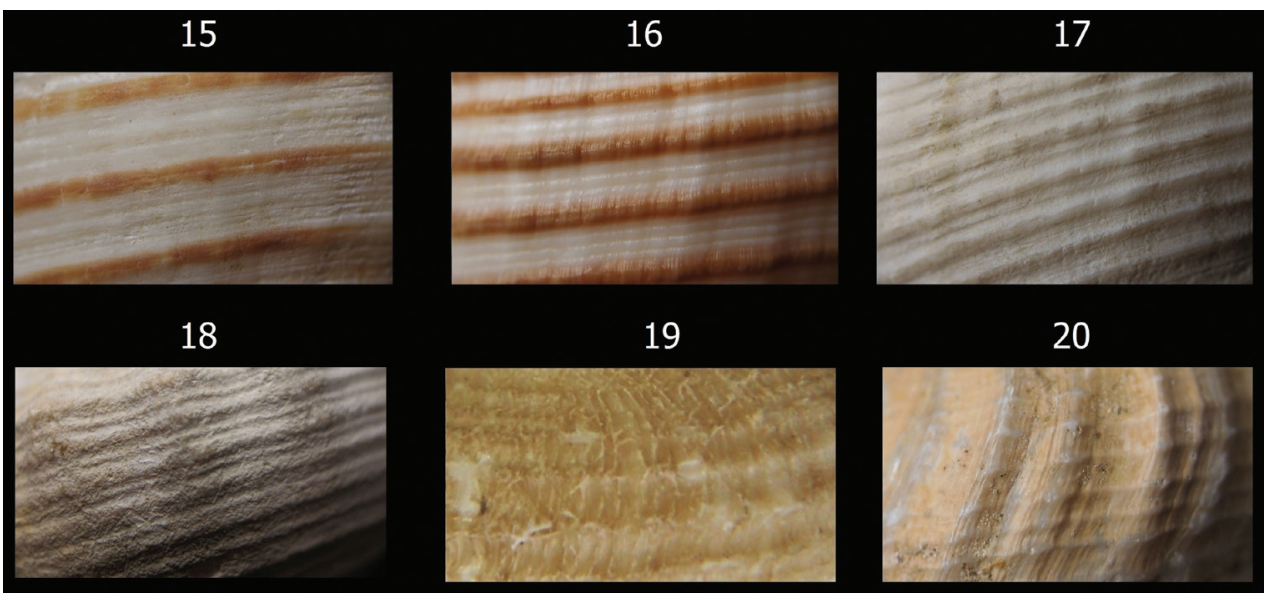

Figures 15-20. Details of shell sculpture of Chilean Aeneator species. 15 A. castillai (RC Coll.), 85.7 mm I6 A. fontainei (RC Coll.), $48.0 \mathrm{~mm} \mathrm{I7} \mathrm{A.} \mathrm{loisae} \mathrm{(MG} \mathrm{200003),} 78$ mm 18 A. martae sp. n. paraype 3 (MG 200105), $40.2 \mathrm{~mm} 19$ A. portentosus, Paratype KF-0338, $45.5 \mathrm{~mm} 20$ A. prognaviter (MG 200124), 33,0 mm.

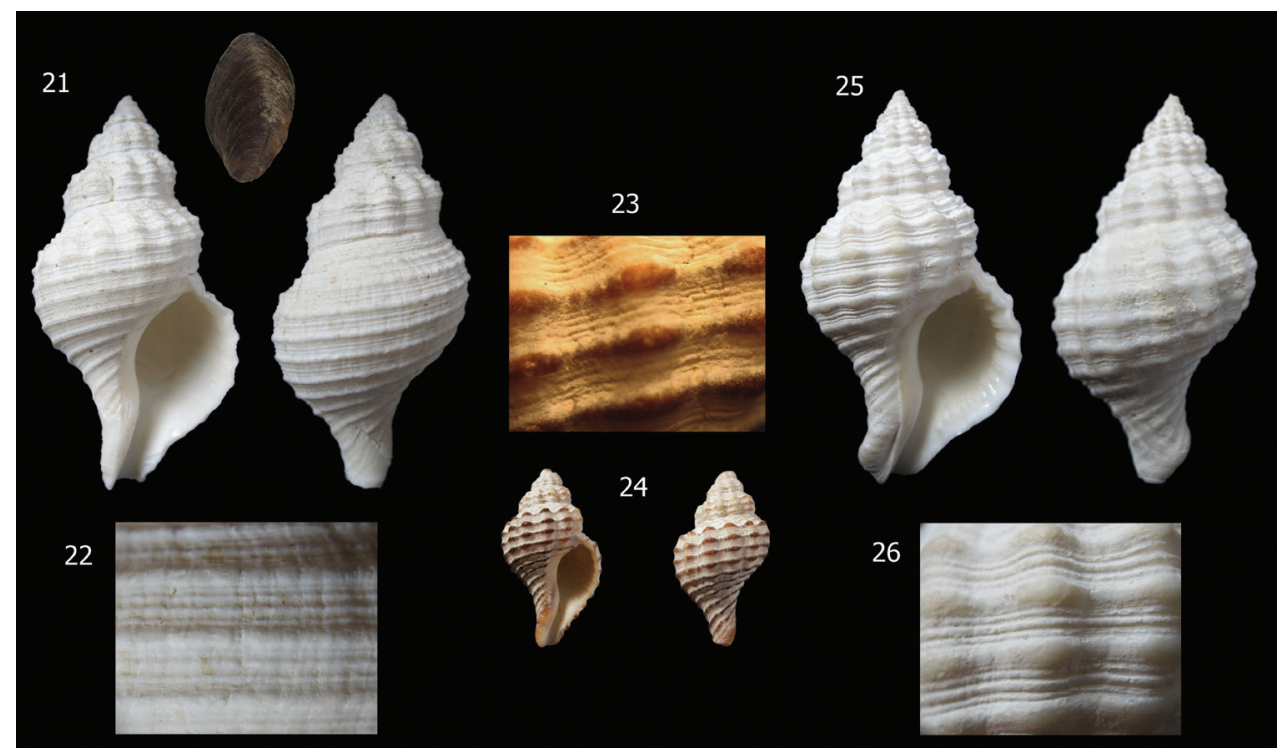

Figures 2I-26. Aeneator fontainei varieties and details of shell sculpture. 2I-22 Off Coquimbo, Chile, trawled $421 \mathrm{~m}$ (RC Coll), 58 mm 23-24 Washed ashore, Calderilla beach, Caldera, Chile (MG 200011), 28.5 mm 25-26 Dredged $20 \mathrm{~m}$ depth off Loreto beach, Caldera, Chile (MG 200012), $52.8 \mathrm{~mm}$.

brown primary spiral cords (Figs 15, 16) and lip lirated within. The spiral sculpture is quite different; $A$. fontainei has 13 to 16 dark brown major cords, with interspaces filled with five secondary cords separated by fine grooves or by secondary and tertiary cords. Aeneator castillai has brown primary cords with 3 to 5 fine secondary cords fill- 


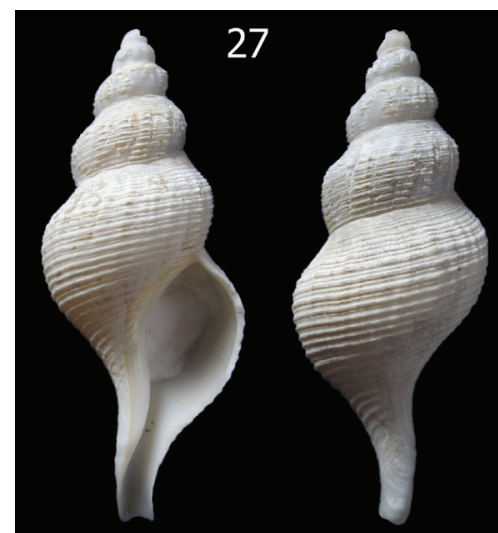

28

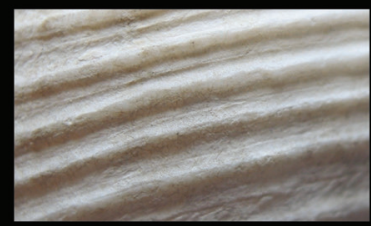

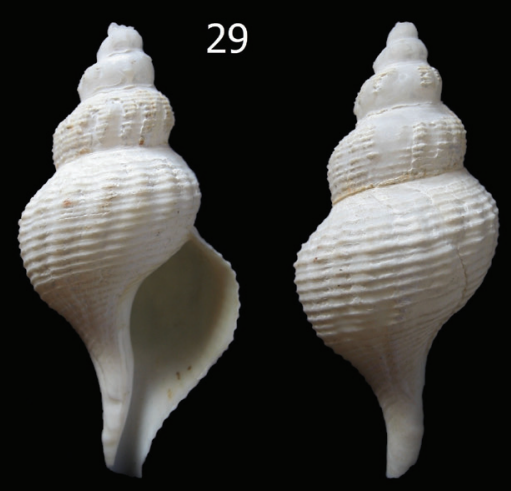

30

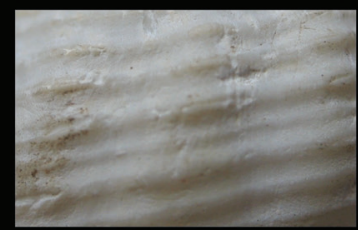

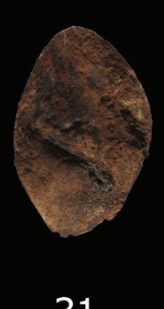

31
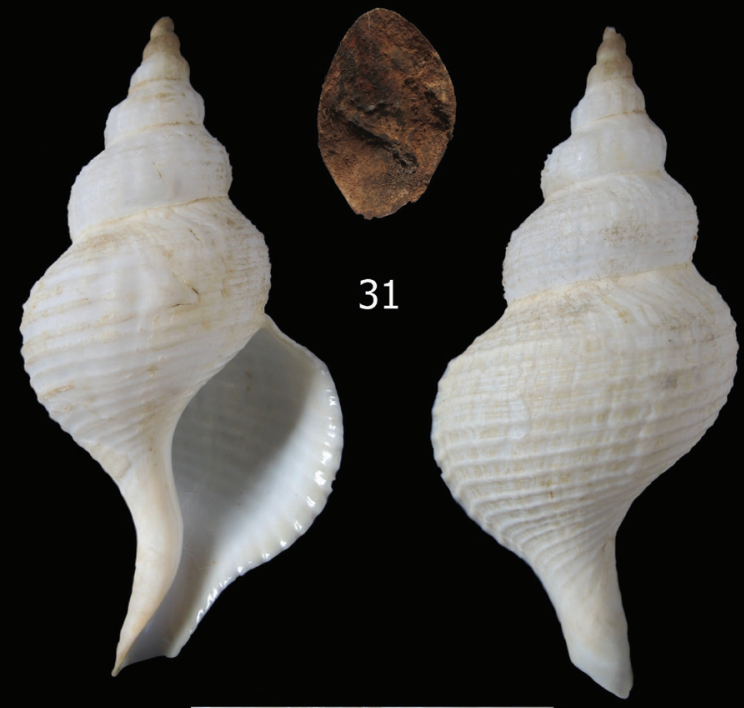

32

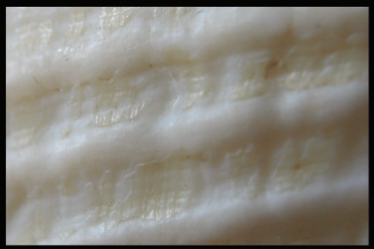

Figures 27-32. Aeneator loisae varieties and details of shell sculpture 27-28 Off Caldera, Chile, 450 $500 \mathrm{~m}$ depth (MG 200003), 78 mm 29-30 Off Caldera, Chile, $420 \mathrm{~m}$ depth (MG 200007) $71.9 \mathrm{~mm}$ 3 I-32 Off Coquimbo, Chile, $400 \mathrm{~m}$ depth (RC Coll.), $104 \mathrm{~mm}$ 
ing the interspaces and exhibits a longer, twisted, siphonal canal. In contrast $A$. martae sp. n. lacks any brown coloration, shows a sculpture of alternated single major and minor spiral cords defined mostly in the posterior part of the whorls, and has a conspicuous stepped shoulder, forming a keel at the periphery.

Aeneator loisae (Figs 27-32) differs from the new species in having a larger, up to $104 \mathrm{~mm}$, white to snow white shell (different from the white to light brown shell of $A$. martae sp. n.), more inflated last whorl, with a much longer siphonal canal, a higher number of primary and secondary spiral cords, more prominent spiral sculpture, and fewer, more tenuous, axial ribs.

The new species is tentatively assigned, given the generic uncertainties within the Chilean species, to the genus Aeneator Finlay 1926, typified by the species A. marshalli marshalli (Murdoch, 1924) recorded from Castlecliff (as fossils) and, as a recent species (= A. marshalli separabilis Dell, 1956), from Wanganui and Ohope beach, Whakatane, New Zealand. Similar to the type species, $A$. martae sp. n. has a fusiform shell with moderately tall spire, shallow sinus in outer lip and a spiral sculpture of cords crossed by axial costae (Beu and Maxwell 1990). The new species differs from A. marshalli in its smaller shell, shorter anterior canal, the absence of nodules along the columellar lip, less inflated whorls and by the presence of a distinct keel at the periphery. From the genus Austrofusus Kobelt, 1879, with the type species Austrofusus glans (Röding, 1798), the new species differs in the smaller size, its thicker shell, more prominent sculpture, the more prominent ridges over the periphery, and the pale orange colour of the aperture, which is white in A. glans (Beu \& Marshall 2010). Comparative characters in the Chilean species of Aeneator are compared in table 2.

In a recent revision of the fossil fauna of Mejillones, north of Chile (Nielsen 2012), the species Aeneator loisae was synonymized with the fossil species Fusus steinmanni Möricke, 1896 into Austrofusus. However, this was based partly on the incorrect conclusion by Beu and Marshall (2010) that A. fontainei is the type species of Austrofusus; this was later corrected by Beu and Marshall (2011). On morphological grounds, the author concurs with McLean and Andrade (1982) and considers that Aeneator (Ellicea) loisae does belong to the genus Aeneator and the sub-genus Ellicea Finlay in Marwick, 1928. However the generic placement of the species A. fontainei, A. castillai, and possibly the new species described here, should be further investigated or even be ascribed to a new genus.

Further study of radular characters, comparative anatomy and DNA will improve the taxonomic placement of the Chilean species. Fossil studies would also give a general insight into the development of the genus and their relationships with the South Pacific related fauna, especially those from New Zealand and adjacent waters.

Comparative material examined: $A$. castillai, Chile, Region of Coquimbo, Coquimbo, 2 specimens RC Coll. A fontainei, Chile, Region of Atacama, Caldera, 3 specimens MG 200011-200013, 5 specimens RC Coll. A loisae, Chile, Region of Atacama, Chile, 4 specimens MG 200003-200006, 1 specimen RC Coll, $A$ prognaviter, 2 specimens MG 200124-200125, A portentosus, 1 specimen (examined from images), KF-0338. 


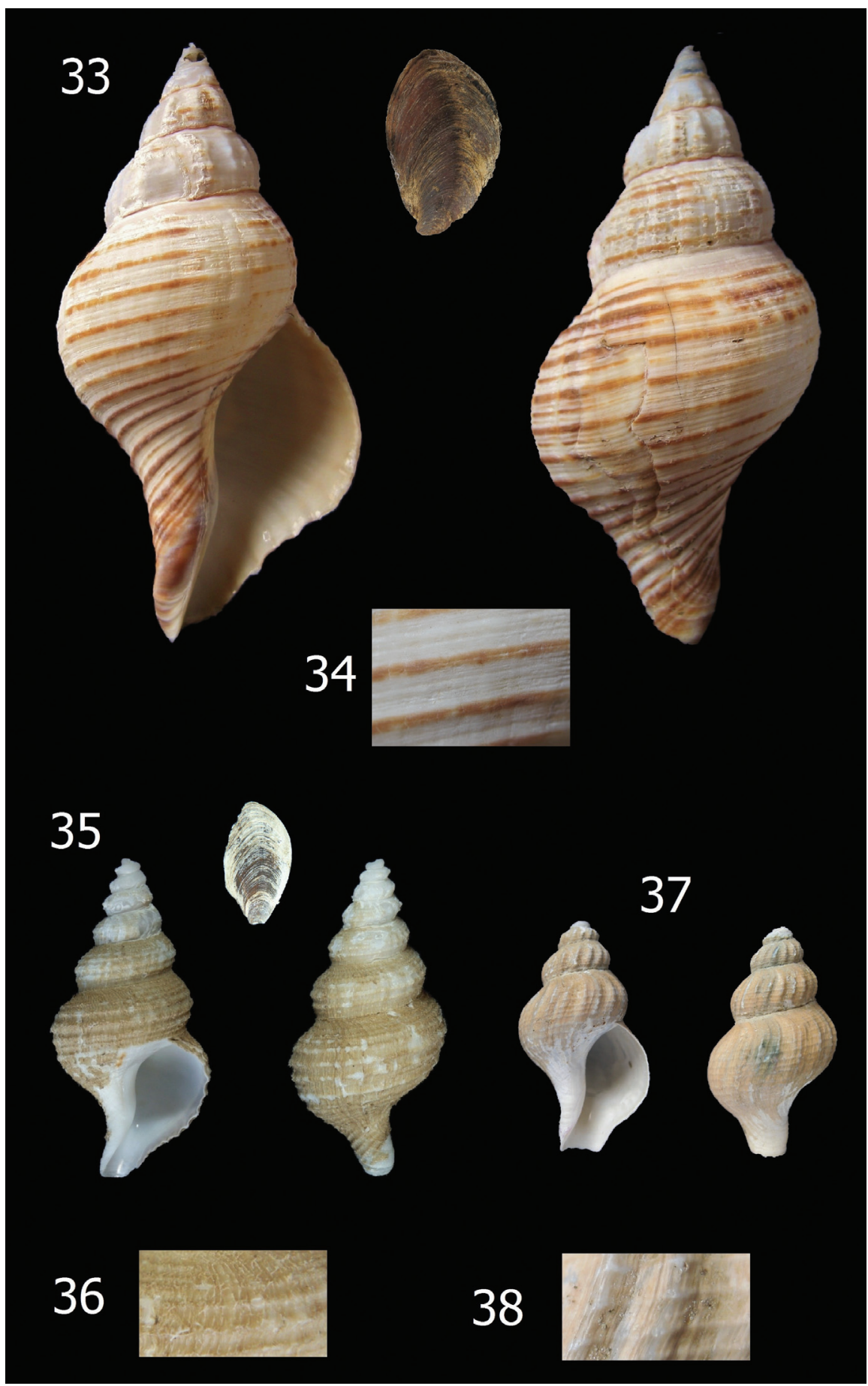

Figures 33-38. Aeneator species and details of shell sculpture. 33-34 A. castillai, off Coquimbo, Chile, $380 \mathrm{~m}$ depth (RC Coll.), 85.7 mm 35-36 A. portentosus, Paratype KF-0338, 45.5 mm 37-38 A. prognaviter, off Iquique, Chile, $748 \mathrm{~m}$ depth (MG 200124), 33,0 mm. 
Key for the identification of fully-grown Chilean species of Aeneator based on shell characters

1 Aperture ovate-elongate

2

- $\quad$ Aperture rounded, shell pagodoid, periostracum sculptured

2(1)

Siphonal canal short.

A. portentosus Fraussen \& Sellanes, 2008

- Siphonal canal long, outer lip reflexed, shell elongated

A. loisae Rehder, 1971

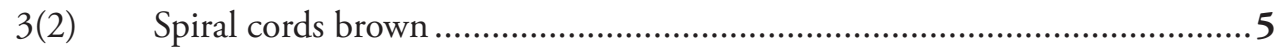

- $\quad$ Spiral cords white, axial ribs thick, shell length up to $49 \mathrm{~mm}$......................4

4(3) Siphonal canal broad, axial ribs strongly curved

A. prognaviter Fraussen \& Sellanes, 2008

- $\quad$ Shell with a distinct keel, aperture almost subquadrate ........A. martae sp. n.

5(3) Axial ribs on subsutural area A. fontanei (d'Orbigny, 1841)

- Sculpture absent on subsutural area, siphonal canal twisted

A. castillai MacLean \& Andrade, 1982

\section{Acknowledgements}

The author wishes to thank Mrs Sandra Castillo for collecting the specimens in situ, Mr Koen Fraussen (Aarschot, Belgium) for sending bibliography and images of the paratype of Aeneator portentosus, commenting about the genus, and reviewing the manuscript. I am grateful to Dr. Guillermo Guzmán (Museo del Mar, Universidad Arturo Prat, Chile) for helping with the specimens of Aeneator prognaviter, Sergio Miquel (Museo Argentino de Ciencias Naturales Bernardino Rivadavia, Buenos Aires, Argentina) for his comments on the early manuscript, Dr. Sven Nielsen (Institut für Geowissenschaften, Christian-Albrechts-Universität zu Kiel, Kiel, Germany) for sending useful bibliography, Mr Ricardo Catalán (Servicio Nacional de Pesca, Chile) for loaning Aeneator specimens for examination from his personal collection, Dr. Alan G. Beu (GNS Science, Lower Hutt, New Zealand) for his comments on the genus, help with essential bibliography, and for his comments and correction of the manuscript. Finally, I would like to thank the reviewers and the academic editor for their very helpful suggestions on the manuscript and the Encyclopedia of Life (EOL) Open Access Support Project (EOASP) for supporting the open access of this paper.

\section{References}

Beu AG, Marshall BA (2010) Austrofusus Kobelt, 1879 replaced by Aethocola Iredale, 1915 in New Zealand (Mollusca: Gastropoda: Buccinulidae). Molluscan Research 30: 53-55. 
Beu AG, Marshall BA (2011) Retraction: Austrofusus glans (Röding, 1798) is the type species of Austrofusus Kobelt, 1879 (Gastropoda: Buccinulidae). Molluscan Research 31: 61-62.

Beu AG, Maxwell PA (1990) Cenozoic Mollusca of New Zealand. New Zealand Geological Survey Paleontological Bulletin 58: 518 pp. http://www.gns.cri.nz/static/Mollusca/p_ bull_58.pdf

Beu AG (1979) Bathyal Nukumaruan Mollusca from Oaro, southern Marlborough, New Zealand. New Zealand Journal of Geology and Geophysics 22(1): 87-103. doi: 10.1080/00288306.1979.10422556

Chiu YW, Chen HC, Lee SC, Chen CA (2002) Morphometric analysis of shell and operculum variations in the viviparid snail, Cipangopaludina chinensis (Mollusca: Gastropoda), in Taiwan. Zoological Studies 41(3): 321-331. http://zoolstud.sinica.edu.tw/Journals/41.3/321.pdf

Dawson EW (1965) Oceanography and marine zoology of the New Zealand Subantarctic. Proceedings of the New Zealand Ecological Society 12: 44-57. http://www.nzes.org.nz/ nzje/free_issues/ProNZES12_44.pdf

Dépraz A, Hausser J, Pfenninger M (2009) A species delimitation approach in the Trochulus sericeus/hispidus complex reveals two cryptic species within a sharp contact zone. BMC Evolutionary Biology 9:171. doi: 10.1186/1471-2148-9-171

Finlay HJ (1926) A Further Commentary on New Zealand Molluscan Systematics. Transactions and Proceedings of the Royal Society of New Zealand 57: 320-485. http://rsnz. natlib.govt.nz/volume/rsnz_57/rsnz_57_00_003550.html

Fraussen K, Sellanes J (2008) Three new buccinid species (Gastropoda: Neogastropoda) From Chilean deep-water, including one from a methane seep. Veliger 50(2): 97-106.

Guzmán N, Saá S, Ortlieb L (1998) Catálogo descriptivo de los moluscos litorales (Gastropoda y Pelecypoda) de la zona de Antofagasta $23^{\circ} \mathrm{S}$ (Chile). Estudios Oceanológicos 17: 17-86. http://www.uantof.cl/recursos_mar/pdf/vol17/vol17_17.pdf

Laudien J, Rojo ME, Oliva ME, Arntz WE, Thatje S (2007) Sublittoral soft bottom communities and diversity of Mejillones Bay in northern Chile (Humboldt Current upwelling system). Helgoland Marine Research 61: 103-116. doi: 10.1007/s10152-007-0057-8

Marwick J (1928) The Tertiary Mollusca of the Chatham Islands including a generic revision of the New Zealand Pectinidae. Transactions and Proceedings of the New Zealand Institute 58: 432-506. http://rsnz.natlib.govt.nz/volume/rsnz_58/rsnz_58_00_003790.html

McLean JH, Andrade H (1982) Large archibenthal gastropods of central Chile: collections from an expedition of the R/V Anton Bruun and the Chilean shrimp fishery. Contributions in Science 342: 1-20.

Nielsen S (2012) A new Pliocene mollusc fauna from Mejillones, northern Chile. Paläontologische Zeitschrift Scientific Contributions to Palaeontology. doi: 10.1007/s12542-0120146-0

Osorio C, Peña R, Ramajo L, Garcelon N (2006) Malacofauna bentónica de los canales oceánicos del sur de Chile ( $\left.43^{\circ}-45^{\circ} \mathrm{S}\right)$. Ciencia y Tecnología del Mar 29(1): 103-114.

Párraga D, Wiff R, Quiroz JC, Zilleruelo M, Bernal C, Azócar J (2012) Caracterización de las tácticas de pesca en la pesquería multiespecífica de crustáceos demersales en Chile. Latinoamerican Journal of Aquatic Resources 40(1): 30-41. http://www.lajar.cl/pdf/imar/ v40n1/Articulo_40_4.pdf 
Powell AWB (1979) New Zealand Mollusca, William Collins Publishers Ltd. Auckland, New Zealand. ISBN 0-00-216906-1

Queirolo D, Erzini K, Hurtado C, Gaete E, Soriguer M (2011) Species composition and bycatches of a new crustacean trawl in Chile. Fisheries Research 110 (1): 149-159. doi: 10.1016/j.fishres.2011.04.001

Rehder HA (1971) A molluscan faunule from 200 meters off Valparaiso, Chile, with descriptions of four new species. Proceedings of the Biological Society of Washington 83(51): $585-596$. 